\title{
Men in Africa: Masculinities, Materiality and Meaning
}

\author{
Tamara Shefer \\ University of the Western Cape
}

Garth Stevens

University of the Witwatersrand

\section{Lindsay Clowes}

University of the Western Cape

Adress correspondence to Tamara Shefer, Private Bag X17, Bellville, 7535, South Africa; email: tshefer@uwc.ac.za

At a public lecture in Cape Town earlier this year, Professor Sandra Harding, an internationally renowned feminist author, spoke to the question 'Can men be subjects of feminist thought?' (1 March 2010, District Six Museum, Cape Town). In her talk, Harding called on men to elaborate critically on their subjective experiences and practices of being boys and men - from childhood to adulthood, and through fatherhood to old age. She argued that while androcentric thinking has dominated knowledge production globally, men's self-reflexive voices on their own experiences of being boys and men have been relatively silent, particularly through a profeminist and critical gender lens. Harding thus drew attention to an important challenge confronting contemporary psychology, a challenge that underpins the rationale for this Special Edition of the Journal of Psychology in Africa. However, much of our knowledge within the discipline of psychology has been and remains uncritically based on boys' and men's experiences and perspectives. More specifically, as Boonzaier and Shefer (2007) argue, most psychological knowledge is not only predominantly based on research with men, but also in most cases, middle-class, white, American men. Studies that problematise and foreground masculinity itself, that challenge masculinity as normative, and that apply a critical, gendered lens, are still relatively marginal in the social sciences and particularly in psychology. This is however beginning to change.

\section{Critically Studying Men and Masculinities: A Growing Field}

What is becoming known as Masculinity Studies, or Critical Men's Studies, represents a relatively new and rapidly expanding research field that draws on theorising emerging from a wide range of disciplines. In acknowledging and foregrounding the social construction of gendered identities and subjectivities internationally (see founding works by Berger et al., 1995; Cornwall \& Lindisfarne, 1994; Connell, 1987, 1995; Hayward \& Mac An Ghaill, 1996; Hearn, 1987; Hearn \& Morgan, 1990; Kimmel, 1987, Frosh, Phoenix \& Pattman, 2002, amongst others), Critical Men's Studies places men and masculinities under the exploratory gaze. Studies that fall within this emerging field recognise that gender expresses the multifaceted and hierarchical relationships between and amongst groups of men as well as between men and women. In addition, such studies often take an intersectional approach that emphasises the culturally and historically specific ways in which masculine subjectivities are co-constructed and mediated by a range of salient subjectivities built around class, race, ethnicity, age, and so on. Such studies insist that men and masculinities be recognised as critical, both socially and politically, and foreground some of the ways in which particular versions of masculinity were and remain a key problem globally and locally. 
Since the seminal works of the late 1980s and 1990s, Critical Men's Studies have become more diverse, complex and nuanced in orientation. Around the globe analysts from a range of disciplines have examined the plasticity of masculinity in a wide range of micro-contexts to expose how certain problematic formulations of masculinity continue to emerge and reemerge in different morphed forms; they have explored the dialectical relationships between masculinity and broader material conditions within societies; they have explored masculinities as discursive productions and enactments; and they have explored the intersectionality between masculinities and post-colonialities. They have also ex- posed both the strengths and weaknesses of masculinity as performativity, and finally, have highlighted the ongoing contestatory nature of subjectivities by illuminating alternative masculine subject positions that may in fact point us in the direction of different and simultaneously more equitable and just ways of being men and women in the worlds that we occupy (Connell 1998, 2000, 2001; Hearn et al., 2006; Kimmel et al., 2005).

Reflecting international trends, the 1990s saw a growing focus on men and masculinities in research on the African continent as well. In Southern Africa for example, The J ournal of Southern African Studies produced a Special Edition on masculinities in 1998 (volume 24,4), and Agenda followed suit later on in the same year (volume 37), and studies focusing on masculinities in Africa began to appear regularly in both local and international journals - far too many to begin listing them here. In addition, over the last decade the continent has seen the publication of several edited collections (see for example, Cleaver, 2002; Gibson \& Hardon, 2005; Lindsay \& Miescher 2003; Morrell 2001a; Ouzgane \& Morrell, 2005; Reid \&Walker, 2005; Richter \& Morrell, 2006; Shefer, Ratele, et al., 2007). Much of this research has been inspired by the imperatives of challenging the spread and impact of HIV/AIDS in Africa, where it has been widely recognised that gender roles and gender power inequalities are strongly implicated (for example, Abdool Karim, 2005; Leclerc-Madlala, 1999; Morrell, 2001b; Pattman \& Chege, 2003; J ewkes, Levin \& Penn-Kekana, 2003; Shefer \& Foster, 2009; Vetten \& Bhana, 2001; Wood, Maforah \& J ewkes, 1998). Alongside this, studies on gender, violence and sexuality have begun to explore the social construction of heterosexual masculinities, particularly between and among young men and boys (Bhana \& Pattman, 2009; Gibson \& Lindegaard, 2007; Salo, 2007; Ratele, Fouten, Shefer, Strebel, Shabalala \& Buikema, 2007; Stevens, 2008; Swart, Stevens, Seedat \& Ricardo, 2002; UNFPA, 2000).

Hearn is just one of several writers to have noted that while patriarchy is dangerous for women and girls, it is also enormously damaging for boys and men (Hearn, 2007). Ratele (2008) has been providing persuasive empirical evidence for the same argument in African contexts. The endemic and pervasive nature of intrapersonal and interpersonal violence has provided an additional impetus for research focusing on men and masculinities, especially within the broader framework of achieving gender justice (United Nations Division for the Advancement of Women, 2004). This has lead, both on the continent and elsewhere, to a substantial shift in the exploratory gaze over the past decade towards understanding masculinity as a subject position that is underpinned by discourses and material conditions that reproduce patriarchal, sexist, and heteronormative social conditions, and that specifically act as the scaffold for a range of psychosocial problems such as violence and unsafe sexual practices.

While this research is enormously valuable and helps contribute to our understandings of interpersonal, intrapersonal and group dynamics, it has not been without criticism. Firstly, much of this research has inadvertently tended to demonise boys and men, constructing them as inherently problematic, and has not always provided a more nuanced picture of the complexities of the social construction of masculinity and the often contradictory experiences of boys and men (Pattman, 2007; Bhana \& Pattman, 2009; Shefer et al.,

$$
\text { https://repository.uwc.ac.za/ }
$$


2007). Secondly, it is also important to note the concerns of some that this increased focus on boys and men may negatively impact on the feminist project aimed at addressing the needs of women and girls, by drawing the focus and resources away from the latter and recentering men. Such anxieties should not be glibly dismissed, but rather alert us to the importance of a critical reflexive assessment of the work we do as researchers and practitioners.

At the same time however, we argue here that the focus on the subjectivities, experiences and practices of boys and men, and the changing and contextually-specific social constructions of these, is an imperative if we are to meaningfully address gendered inequalities that simultaneously privilege men and marginalise women. If such a focus is always managed within a critical and feminist methodology that attempts to avoid reinvisibilising women's experiences, then a focus on men and masculinity can contribute to the broader political project of empowering women. That the majority of the papers collected here explore the experiences and understandings of young men speaks to the inherently feminist agenda of the researchers. Understanding the complex social pressures and imperatives confronting young men as they struggle to establish masculine identities and perform masculinity contributes towards interventions that aim to empower young men to develop non-violent, non-abusive, less risky versions of masculinity in favour of masculinities that are more life affirming and life enhancing to the benefit of all. Recognising that certain recalcitrant formulations of masculinity are harmful to men as well as women thus serves to broaden the nature of political and ideological projects that aim to empower women.

That a substantial body of work under the broad framework of Masculinities or Critical Men's Studies now exists is clear. And yet, although psychology has long concerned itself with gender, and this is especially evident in the sub-disciplines of personality theory and human development, psychology as a discipline and profession has turned a blind eye to many new developments in gender critique, even while presenting itself as the authority on gender identity and development. It has, to put it bluntly, largely failed to incorporate a critical gendered lens and to engage with the contributions of feminist and Critical Men's Studies outlined above. With a few exceptions, a conscious and critical focus on boys and men that draws on these insights remains on the margins of mainstream psychology. In responding to these lacunae within the extant psychological literature, this Special Edition aims to contribute to the broad discipline of psychology as well as to the sub-disciplines of research, clinical and educational psychology. While the collection draws on the contemporary research of some of those who have already published in the field, it also provides an opportunity for new and emerging researchers to share their findings and it is hoped that psychology as a discipline will take on and develop the theorising and insights they present.

\section{The Special Edition and Some Silences}

All the papers in the collection reflect critically on how masculinities are socially constructed and historically and contextually specific. In addition, they attempt to give voice to the subjective experiences of boys and men and to foreground these lived experiences and understandings of gendered identities in ways that challenge default positions that men are always privileged perpetrators of gendered power inequalities. The collection as a whole insists that boys and men are produced within specific material conditions, through performances of masculinities that are relational, and are therefore complex subjects that are constituted through negotiation with women, femininities as well as other men - against the backdrop of broader material, symbolic and discursive terrains.

It is unfortunate that most of the papers in this Special Edition represent Southern African contexts, with only one study exploring masculinities outside sub-Saharan Africa. It is also disappointing that the vast majority of papers are written by South

$$
\text { https://repository.uwc.ac.za/ }
$$


African researchers, or speak about South African experiences. While this may reflect a scarcity of researchers doing work on masculinities on the continent, as well as the current proliferation of such research in Southern African contexts, it may also relate to the location of the editors and their networks. While the call was distributed to an African network of gender researchers (the GWS network hosted by the African Gender Institute) and through the Journal of Psychology in Africa, the question of the relative silence from other countries on the continent on men, boys and masculinities remains. Such a silence may also be read as flagging the persistence of historical power dynamics in knowledge production processes regionally, and more broadly. In South Africa, for example, the dominance of white and male authorship, continues to reflect the historical divides of apartheid and the privileges of class, race and gender and thus impacts on who publishes and whose work is acknowledged (for a more detailed discussion of these issues, see for example, the Special Edition of the South African J ournal of Psychology, 2004, that reflects on this troubling challenge for knowledge production in Psychology in South Africa). Such patterns of power and privilege with respect to publishing may also be evident on the continent and may reflect regional power dynamics.

A number of key themes emerge out of the papers that are included in this Special Edition and reflect focus areas in the broader literature as well. All the papers employ qualitative methodologies to speak to the complexity of masculinities, how these are enacted at subjective and social levels, and in multiple and often contradictory ways. They therefore flag a clear role that psychology and psychological theorising may play in developing new and more nuanced knowledges about boys, men and masculinities in particular African contexts. The papers also highlight how a socially and contextually specific psychological focus on men and boys ties in with the goal of addressing some of the major challenges that many African countries and com- munities have in common, such as poverty, violence, gender in- equalities, socio-political instability, and ill-health.

\section{Fatherhood and Men's Practices of Fathering}

Fatherhood features strongly in the literature on boys and men, internationally and in the African context (see for example, Richter \& Morrell, 2006; Swartz \& Bhana, 2009), since the centrality of the role of breadwinner and head of the family and home has been shown to be a key marker of masculinity in many empirical studies on boys and men (for example, Silberschmidt, 2001; Mfecane, 2008; Ampofo \& Boateng, 2007; Morrell, 2007). A number of papers in this edition focus specifically on or include reflections on fatherhood. In drawing on a larger study as published in the book reviewed later in the edition, Hendricks et al. reflect in detail on a series of in-depth interviews with young men in the Western Cape and Kwazulu-Natal regions of South Africa who aimed to become fathers and who fulfilled this aim before they turned 20 years of age. In challenging popular narratives that position men as largely absent fathers, Hendricks et al. insist that the social and historical contexts in which these young men wanted to become fathers is important in explaining both their choices and reactions to impending and actual fatherhood. Poverty, for example is understood to be a risk factor for early fatherhood in that it provides a public recognition of claims to masculinity built around 'ownership' of female bodies. At the same time though, being a father is also understood to mean providing, and while some are able to meet this obligation, poverty and unemployment mean others struggle.

While still foregrounding fatherhood, Malose Langa takes a slightly different approach in his paper where he explores the ways in which young men aged between 14 and 18 years talk about their experiences of being fathered. Langa provided his participants with disposable cameras and asked them to take pictures with the theme 'my life as a boy'. Individual and group discussions of these images provide the data for the subsequent analysis. While reinforcing the popular narrative that many of these young men either

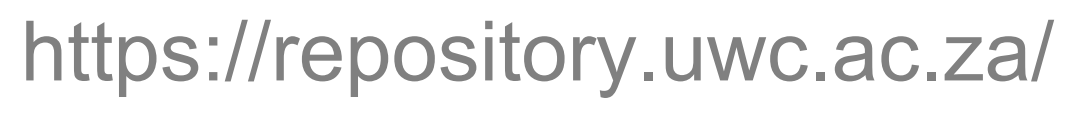


did not know or had very limited contact with their fathers, their aspirations represented challenges to such narratives. Importantly, these young men aspired to be 'different' from their own fathers, and resisted following the model of their own fathers, and hoped to embrace alternative visions of adult masculinity and a more engaged and present fatherhood. One of the more interesting findings in this paper that also challenges traditional psychological notions of the importance of a father figure for boys is the way in which many of the boys admired their mothers and viewed them as positive role models for positive adulthood and respectable citizenship. While this finding clearly needs more investigation, it is encouraging that the young men interviewed valued and appreciated the role of their mothers, acknowledging their strength in their positions as single parents. A number of other papers in this edition also highlight the salience of the position of fathers and the role of fathers in the family as a key marker of masculinity across different cultures and contexts, even though this may not be the primary focus. Bjarke Oxlund and his co-authors for example also flag the significance of the family for men in the uniformed forces in Rwanda where they are forced to be away from their families for long periods of time, and the importance of the fatherhood position as a significant marker of successful masculinity for them.

While Reshma Sathiparsad's article on attitudes towards teenage pregnancy focuses primarily on young people's attitudes and reported practices towards sexuality, the paper also highlights some aspects relating to parenting. One of the important findings in this respect is that it seems that the young rural men who participated in her study (KwaZulu-Natal, South Africa), still see the female partner as responsible for pregnancy and admit that she will suffer the brunt of negative responses from the community, the school authorities, teachers as well as from her own peers. A sense of responsibility by young men for their partners' pregnancies, and therefore parenting, appeared to be absent in the responses of participants, and the sentiment that getting your girlfriend pregnant may even be a beneficial illustration of one's sexual prowess was also articulated. Sathiparsad argues that even while her survey results show that the majority of boys see themselves as equipped to be good fathers, focus group findings reveal an ambivalence about such a possibility, from both a financial and social point of view (mirroring the recent study by Swartz \& Bhana, 2009).

The centrality of fatherhood for men and its social construction in society is clearly problematic for many men and has to be understood in socio-economic as well as ideological contexts. In many societies pressures on men to be breadwinners and heads of households has been shown to undermine their sense of self-value and successful masculinity particularly for poor men (see for Richter \& Morrell, 2006) who find themselves unable to live up to this expectation, as well as men who for other reasons such as being ill (for example those living with HIV) are unable to earn a living and support their families (see Mfecane, 2008). Nonetheless, these papers also foreground the importance for men of being a part of their families and playing a role as a parent, and on the positive side with respect to gender transformation, speak to an emerging desire from a new generation of men who may want to father differently.

\section{Male Sexuality}

A focus on male sexuality, and heterosexuality in particular, has been accelerated by the imperative to challenge the HIV/AIDS epidemic in Africa. Research has proliferated particularly in sub-Saharan Africa, where the rates of infection are still high, despite many years of prevention efforts. The centrality of gender roles and gender power relations in understanding the challenges to safe sexual practices has been widely acknowledged. Increasingly the gaze has turned from an initial focus on women and female sexuality to looking at men and male sexuality, specifically men's understandings of their sexuality in relation to their intimate relationships with women. A number of the papers in this edition focus on questions of sexuality and underline the interconnectedness of sexuality and

$$
\text { https://repository.uwc.ac.za/ }
$$


gender - of the ways in which heterosexual practices are central to dominant performances of masculinity. Bronwynne Anderson's research with boys from a working class neighbourhood in Kwazulu-Natal in South Africa for example, highlights the manner in which young men perform masculinity as misogynistic and as at times simultaneously caring. In locating these young men historically, she points out how their historical marginalisation as poor, minority men of colour has contributed to their hyper-sexualised discursive reproduction in relation to women and their construction of themselves as anti-authoritarian through positioning themselves as 'troublesome'. On the other hand, the study also shows how such young men also engage in more positive responses to girls and women as they simultaneously leave room for more affectively loaded and caring relationships with key women in their lives.

Pointing to the necessity of understanding local contexts with respect to male sexuality and masculinity is the Rwandan study by Bjarke Oxlund, Lise Rosendal Ostergaard and Geoffrey Ngirowonsanga Kayonde, which demonstrates the di- versity in constructions of masculinity and male sexuality across the continent. The centrality of sexuality in the construction of masculinity as articulated through practices of multiple partners and casual sex with women constructed as objects for male gratification has been well documented in the Southern African context (for example, Lindegger \& Maxwell, 2007; MacPhail \& Campbell, 2001; Pattman \& Chege, 2003; Ratele 2006; Shefer \& Foster, 2009). In contrast, Oxlund et al. explore different versions of male sexuality in their case study of Rwandan men in uniforms. In this particular context, we hear that dominant performances of heterosexual masculinity foreground practices by which men address female desires, and privilege female plea- sure through practices of wet sex. In marked contrast with the reports about dominant masculinities in South Africa alluded to above, the Rwandan men involved in this study insisted that real men were faithful to their wives or partners, agreeing that even though many men took multiple partners, this reflected very badly on them as men. Nyameka Mankayi's study also explores constructions of masculinity and sexuality amongst men in uniforms - in this case a group of military personnel in South Africa. This paper highlights the pervasiveness of contradictory discourses in which men articulate a human rights discourse about women's rights to refuse sex with their male partners on the one hand, while on the other, women's refusals are under- stood as challenges to men. The paper then suggests ways in which the military context and its historical ethos of masculine aggression, exaggerates dominant expectations of men's performances of masculinity and sexuality, and even potentially facilitates and legitimises coercive sexuality under specific material conditions (for example, during periods of deployment). While the paper concludes with some tentative thoughts about transformation in the military as an institution, its value is fundamentally in its critique of the military as an incubatory environment for potentially problematic forms of masculinity to be amplified.

Reshma Sathiparsad's study on attitudes to teenage sexuality also provides important insights into male sexuality in a rural South African context where she supports the argument of other South African researchers that dominant forms of masculinity compromise the health and well-being of young men since riskiness is conflated with successful masculinity. The 'male sexual drive' discourse, documented by many local researchers and internationally, was highlighted as pervasive in her study where young men experience the imperative to prove their sexual prowess through multiple partner and casual sex - 'to take sex lightly' as she argues. The study also however highlights the vulnerability of young men with respect to fears of achieving this, and their anxieties about rejection by girls, both of which re- iterate in some ways the more vulnerable and caring discourse documented in Anderson's study.

\section{https://repository.uwc.ac.za/}




\section{Doing Masculinity}

Most of the papers present evidence for post-structuralist and queer perspectives on gender - understandings that posit gender identities as performances (Butler, 1990) and practices. These perspectives foreground the importance of gender as constantly in tension, always in the process of being formed and re-formed through what we do and how we do it in negotiation with others, thus co-constructed by boys and girls, men and women. The notion of an internal and stable gender identity has been firmly displaced by notions of doing gender (West \& Zimmerman, 1987). Thus, the paper by Kopano Ratele, Tamara Shefer, Anna Strebel and Elron Fouten presents an account of performativity of gender by a group of adolescent boys in some communities in Cape Town, and foregrounds the importance of gender stereotyped activities in the construction of masculinity. The paper also illuminates the imperative for boys and young men (as documented elsewhere locally and internationally) to ensure that one does not 'perform' as female or gay in the achievement of successful masculinity, but rather actively dis- tances from non-hegemonic masculine activities as well as what are constructed as feminine ways of acting.

The paper by Rob Pattman and Deevia Bhana, focusing on black and Indian boys at a formerly white elitist boys' high school near Durban shows how the doing of masculinity in this context is powerfully raced and gendered. The authors argue how these boys' accounts of their experiences of schooling, specifically as played out through sport, were in sharp contrast to the way the school presented itself as a multi-cultural boys' school promoting positive 'race relations' and forms of respect. Rather, the study confirms continued divisions and identifications along the lines of gender and race at this school, and the experience of racialised marginalisation for black and Indian boys across the historical apartheid divides that privilege white boys and that are played out through sexual, gender and racial discourses. Importantly, the study also highlights resistances in the narratives of these boys and flag the role of humour in shaping their identities positively. Similarly, it is the intersectionality of race and class that is central to the study by Dimakatso Sedite, Brett Bowman and Lindsay Clowes, a study that foregrounds the powerful association of risk-taking with hegemonic masculinities that may be exaggerated in poor, urban settings.

\section{Male Violence}

Finding ways to challenge violence against women and children is an international imperative that has also been foregrounded in many African countries as a key psychosocial problem. The complex enmeshment of violence with masculinity has been theorised in multiple ways with many studies illustrating the way in which hegemonic forms of masculinity serve to facilitate, encourage and legitimise violent practices by men towards other men, women and children (see for example, Clowes, Lazarus \& Ratele, 2010; Ratele 2008; Gibson \& Lindegaard, 2007; ). It is not therefore surprising that a number of the papers speak to the role of violence in the social construction of masculinity and how violence is interwoven with dominant ways of being a boy and man.

The focus on male violence against female intimate partners is taken up in a complex manner in the paper by Ursula Lau and Garth Stevens, who argue that we need to embed our understandings of such violence in historically and culturally specific social constructions of masculinity, while acknowledging intrapsychic and individual processes of subjectivity. While the authors understand male violence as socially constructed, they argue for a feminist-psychoanalytic approach to show how men interiorise and reproduce gendered forms of violence and hegemonic constructions of gendered relations. Lau and Stevens explore the ways in which men rely on violenœe to disavow 'feminine' aspects of the self in order to maintain a socially accepted masculine identity.

\section{https://repository.uwc.ac.za/}


The relationship between masculinity and violence is also the focus of the paper by Diana Gibson, although she approaches it from a novel angle and in a particular historical and social context. Gibson gives voice to the narratives of white, male military veterans of the 'Bush War' in Namibia. The paper's central argument is that hegemonic forms of masculinity have undermined these men's ability to articulate their vulnerability and trauma as a result of their exposure to and participation in violence, since such articulations appear as unmanly. Moreover, in the political context of post-apartheid South Africa, the lack of legitimacy or space for the acknowledgement of trauma among this particular group of South Africans has further impacted on their ability to deal with the ongoing effects of these memories on their psychosocial well-being. Mankayi and Oxlund et al. also refer to the ways in which violence is so often naturalized amongst men, and discursively appropriated and deployed in militarised contexts, to give rise to a social context in which men's violence is simultaneously legitimised and their non-violence or abject reactions to violence delegitimised. At the same time however, Oxlund et al.'s study demonstrates the importance of social context in producing alternative versions of masculinity, and points to the need for further research in diverse locations.

\section{Men, Boys and Risk}

Linked to the focus on violence has been the strong association of masculinity with physical performance and activity. Risk-taking in particular has been theorised and documented ethnographically, with studies around the world suggesting that in many communities and societies young men (and to a much lesser extent young women) are expected to engage in a wide range of risky behaviours. In South Africa, for example, smoking, drinking, drug taking, gangsterism, having multiple sexual partners, taking physical risks such as fighting or 'dicing' with motorcars are associated with young men far more often than they are with young women (Clowes et al., 2010; Mager, 2010; Reddy, Panday, Swart, Jinabhai, Amosun, James, Monyeki, Stevens, Morejele, Kambaran, Omardien \& Van den Borne, 2003; Salo 2007). Thus, Dimakatso Sedite, Brett Bowman and Lindsay Clowes draw attention to the sometimes deadly 'sport' of trainsurfing by young, urban boys and men in poor communities in South Africa, insisting that the practice needs to be understood as rooted in the apartheid legacy of racialised, gendered and classed inequalities. But rather than exploring the ways in which young men themselves understand their risky practices, the paper underlines the ways in which gender is performative by reflecting on some of the ways in which train surfing is 'read' by the railway authorities, officials and passengers who are the apprehending audience. Sedite et al. argue that race, class and gender intersect to facilitate a vulnerability to risk-taking practices among urban youth in South Africa - an intersectional nexus that reveals how risk-taking is not only a source of affirming a certain hegemonic form of heroic masculinity, but also an anti-authoritarian subject positioning among working class, urban, young men.

\section{Resistance and Challenge}

Much of the recent work on gender emphasises the importance of identifying discourses and practices that reflect resistances to dominant discourses, and that speak to the way in which people and societies are changing and challenging dominant gender roles and relations. Speaking of boys and men who do gender differently, or who can at least imagine a different way of being a man, and who resist problematic practices of masculinity, have all been increasingly documented within the Critical Men's Studies literature. The paper by Nick Davies and Gillian Eagle specifically addresses the experiences of men who occupy what have traditionally been understood as stereotypically female roles in Western societies, to highlight some of the challenges of stepping outside of stereotypically male roles, and the ways in which class and social location mediate the possibilities of challenging hegemonic norms. Davies and Eagle suggest that those young men who do engage in the nurturing, caring, libidinal labour

\section{https://repository.uwc.ac.za/}


that (at least in the West) has tended to be seen as women's work, find themselves in need of an 'overcoat of masculinity' in which they recast their work as masculine rather than feminine. The salience of resistant and contradictory discourses of masculinity that offer new and alter- native ways of being a boy, a man, or a father are the subject of several of the papers. Thus, the papers by Anderson, Pattman and Bhana and Langa all demonstrate the ways in which young men, especially when faced with the challenges of racism or poverty, make positive meaning of their identities and reconstruct alternative versions of being a man.

\section{Conclusion}

Overall, while there are differences in approach, in focus and in the contexts explored, a number of key themes emerge out of the papers gathered together in this Special Edition. Firstly, it seems clear that there are a range of pressures on young males to behave in particular ways, specifically to behave in ways that are similar to those of older males in their communities, and that are different to the behaviours of girls and women. At the same time, older males are themselves expected to conform to prevailing orthodoxies with regard to the practices labeled as masculine at any one time or place, often at great cost to themselves and others. Challenging these costly normative practices however also has a price in terms of peer acceptance as some of the papers illustrate, for stepping outside contextually appropriate gender roles may have punitive consequences for both boys and men. And yet, as the papers also reveal, challenges to hegemonic and often harmful (both to themselves and others) masculinities are being widely articulated by boys and men across diverse contexts in Africa. It is important that, as psychologists, we deepen our understanding of the constraints and possibilities confronting men who hope to construct life embracing and more affirming versions of masculinity. 


\section{References}

Abdool Karim, Q. (2005). Heterosexual transmission of HIV: The importance of a gendered perspective in HIV preven- tion. In S. Abdool Karim \& Q. Abdool Karim (Eds.),HIV/ AIDS in South Africa (pp. 243-261). Cape Town, South Africa: Cambridge University Press.

Agenda (1998). The new men? Special issue. Agenda, 37. Ampofo, A. A., \& Boateng, J . (2007). Multiple meanings of man-hood among boys. In. T. Shefer, K. Ratele, A. Strebel, N. Shabalala, \& R. Buikema (Eds.), From boys to men: Social constructions of masculinity in contemporary society (pp. 50-74). Cape Town, South Africa: UCT Press.

Berger, M., Wallis, B., \& Watson S. (Eds.) (1995). Constructing masculinity. New York, NY: Routledge.

Bhana, D., \& Pattman, R. (2009). Researching South African youth, gender and sexuality within the context of HIV/ AIDS. Development, 52(1), 68- 74.

Boonzaier, F., \& Shefer, T. (2006). Gendered research. In T. Shefer, F. Boonzaier, \& P. Kiguwa (Eds.), The Gender of Psychology (pp. 3-11). Cape Town, South Africa: UCT Press.

Butler, J . (1990). Gender trouble: Feminism and the subversion of identity. New York, NY: Routledge.

Cleaver, F. (2002). Masculinities matter: Men, gender and de- velopment. Cape Town, South Africa: David Philip.

Clowes, L., Lazarus, S., \& Ratele, K. (2010). Risk and protective factors to male interpersonal violence: The views of some male university students. African Safety Promotion, 8(1), 1- 19.

Connell, R. W. (1987). Gender and power: Society, the person and sexual politics. Cambridge, England: Polity Press. Connell, R. W. (1995). Masculinities. Cambridge, England: Polity Press.

Connell, R. W. (1998). Masculinities and globalisation. Men and masculinities, 1(1), 3- 23.

Connell, R. W. (2000). The men and the boys. Berkeley, CA: University of California Press.

Connell, R. W. (2001). Studying men and masculinity. Re- sources for Feminist research, 18, 43- 57.

Connell, R. W. (2002). Gender. Cambridge, England: Polity Press.

Cornwall, A., \& Lindisfarne, N. (Eds.) (1994). Dislocating masculinity: Comparative ethnographies. London, England: Routledge.

Frosh, S., Phoenix, A., \&Pattman, R. (2002). Young masculinities: Understanding boys in https://repository.uwc.ac.za/ 
contemporary society. London, England: Palgrave.

Gibson, D., \& Hardon, A. (Eds.). (2005). Masculinity, violence and AIDS: Issues related to health. Amsterdam, Nether- lands: Het Spinhuis.

Gibson, D., \&Lindegaard, M. R. (2007). South African boys with plans for the future: Why a focus on dominant discourses tells us only a part of the story. In T. Shefer, K. Ratele, A. Strebel, N. Shabalala, \& R. Buikema (Eds.), From boys to men: social constructions of masculinity in contemporary society (pp. 128-144). Cape Town, South Africa: UCT Press.

Hayward, C., \& Mac an Ghaill, M. (1996). Men and masculini- ties. Buckingham, England: Open University Press.

Hearn, J. (1987). The gender of oppression: Men, masculinities and the critique of Marxism. Brighton, England: Wheatsheaf.

Hearn, J. (2007). The problems boys and men create, the problems boys and men experience. In T. Shefer, K. Ratele, A. Strebel, N. Shabalala, \& R. Buikema (Eds.), From boys to men: Social constructions of masculinity in contemporary society (pp.13-32). Cape Town, South Africa: UCT Press.

Hearn, J., \& Morgan, D. (Eds.). (1990). Men, masculinities and social theory. London, England: Unwin Hyman.

Hearn, J., \& Pringle, K., with members of Critical Research on Men in Europe (2006). European perspectives on men and masculinities. Houndsmills, UK: Palgrave Macmillan.

J ewkes, R. K., Levin, J. B., \& Penn-Kekana, L. A. (2003). Gender inequalities, intimate partner violence and HIV preven- tive practices: Findings of a South African crosssectional study. Social Science \& Medicine, 56 (2003), 125- 134.

J ournal of Southern African Studies (1998). Special edition on masculinities in Africa. J ournal of Southern African Studies, 24(4).

Kimmel, M. (Ed.). (1987). Changing men: New directions in re search on men and masculinity. Newbury Park, CA: Sage. Kimmel, M.S., Hearn, J ., \&Connell, R. W. (Eds.). (2005). Handbook of studies on men and masculinities. London, England: Sage.

Leclerc-Madlala, S. (1999). Demonising women in the era of AIDS: An analysis of the gendered construction of HIV/AIDS in KwaZulu-Natal (Doctoral thesis). University of Natal, Durban, South Africa.

Lindegger, G., \& Maxwell, J. (2007). Teenage masculinity: the double bind of conformity to hegemonic standards. In T. Shefer, K. Ratele, A. Strebel, N. Shabalala, \& R. Buikema (Eds.), From boys to men: Social constructions of masculinity in contemporary society (pp. 94 - 111). Cape Town, South Africa: UCT Press.

Lindsay, L., \& Miescher, S. F. (2003). Men and masculinities in modern Africa. London, England: Heinemann.

\section{https://repository.uwc.ac.za/}


MacPhail, C., \& Campbell, C. (2001). “T think condoms are good, but aai, I hate those things": Condom use among adolescents and young people in a South African township. Social Science \& Medicine, 52, 1613- 1627.

Mager, A. (2010). Beer, sociability and masculinity in South Africa. Cape Town, South Africa: UCT Press

Mfecane, S. (2008). Living with HIV as a man: Implications for masculinity. Psychology in Society, 36, 45- 59.

Morrell, R. (Ed.). (2001a). Changing men in Southern Africa. London \& New York, NY: Zed books.

Morrell, R. (2001b). Silence, sexuality and HIV/ AIDS in South Africa. Gender, sexuality and HIV/AIDS: Research and intervention in Africa. The Australian Educational Researcher, 30(1), 41-62.

Morrell, R. (2007). Do you want to be a father? Schoolgoing youth in Durban schools at the turn of the 21st century. In T. Shefer, K. Ratele, A. Strebel, N. Shabalala, \& R. Buikema (Eds.), From boys to men: Social constructions of masculinity in contemporary society (pp. 75- 93). Cape Town, South Africa: UCT Press.

Ouzgane, L., \& Morrell, R. (Eds.). (2005). African masculinities: men in Africa from the late nineteenth century to the present. NewYork, NY: Palgrave Macmillan.

Pattman, R. (2007). Researching and working with boys and young men in Southern Africa in the context of HIV/AIDS: A radical approach. In T. Shefer, K. Ratele, A. Strebel, N. Shabalala, \& R. Buikema (Eds.), From boys to men: Social constructions of masculinity in contemporary society (pp. 33-49). Cape Town, South Africa: UCT Press.

Pattman, R., \& Chege, F. (2003). Finding our voices: Gendered \& sexual identities and HIV/AIDS in education. Nairobi, Kenya: UNICEF.

Ratele, K. (2006). Rulingmasculinity and sexuality. Feminist Af- rica 6, 48- 64.

Ratele, K(2008). Masculinity and male mortality in South Africa. African Safety

Promotion: A J ournal of Injury and Violence Prevention, 6(2), 19-41.

Ratele, K., Fouten, E., Shefer, T., Strebel, A., Shabalala, N., \& Buikema, R. (2007). 'Moffies, jocks and cool guys": boys' accounts of masculinity and their resistance in context. In T. Shefer, K. Ratele, A. Strebel, N. Shabalala, \& R. Buikema (Eds.), From boys to men: social constructions of masculin ity in contemporary society (pp. 112-127). Cape Town, South Africa: UCT Press.

Richter, L., \& Morrell, R. (Eds.). (2006). Baba? Men and father- hood in South Africa. Pretoria, South Africa: HSRC Press.

Reddy, S. P., Panday, S., Swart, D., Jinabhai, C. C., Amosun

S. L., James, S., . . . Van den Borne, H.W. (2003). The South African youth risk behaviour survey 2002. Cape Town, South Africa: Medical Research Council.

Reid, G., \&Walker, L. (Eds.). (2005). Men behaving differently: South African men since 1994. Cape Town, South Africa: J uta Double Storey.

\section{https://repository.uwc.ac.za/}


Salo, E. (2007). Social construction of masculinity on the racial and gendered marhgins of Cape Town. In T. Shefer, K. Ratele, A. Strebel, N. Shabalala, \& R. Buikema (Eds.), From boys to men: Social constructions of masculinity in contemporary society (pp. 160- 180). Cape Town, South Africa: UCT Press.

Shefer, T., \& Foster, D. (2009). Heterosex among young South Africans: research reflections. In M. Steyn \& M. Van Zyl (Eds.), The price/ the prize: Shaping sexualities in the new South Africa (pp. 267- 289). Cape Town, South Africa: HSRC Press.

Shefer, T., Ratele, K., Strebel, A., Shabalala, N., \& Buikema, R. (Eds.). (2007). From boys to men: Social constructions of masculinity in contemporary society. Cape Town, South Africa: UCT Press.

Silberschmidt, M. (2001). Disempowerment of men in rural and urban east Africa: Implications for male identity and sexual behavior. World Development, 29(4), 657- 671.

South African J ournal of Psychology (2004). Special Edition on Authorship. South African J ournal of Psychology, 34(4).

Stevens, G. (2008). Men and meanings of murder: Discourses and power in narratives of male homicide in South Africa. (Unpublished doctoral thesis). University of South Africa, Pretoria, South Africa.

Swart, L., Seedat, M., Stevens, G., \& Ricardo, I. (2002). Violence in adolescents' romantic relationships: Findings from a survey amongst school-going youth in a South African community. J ournal of Adolescents, 25, 385- 395.

Swartz, S., \& Bhana, A. (2009). Teenage tata: Voices of young fathers in South Africa. Cape Town, South Africa: HSRC \& Save the Children Sweden.

United Nations Division for the Advancement of Women (2004).The role of men and boys in achieving gender equality. http:// www.un.org/ womenwatch/ daw/ egm/ menboys2003/r eports/ Finalreport.PDF (Accessed 24 August 2010).

UNFPA (2000). Men, reproductive rights and gender equity. Chapter 4 of the UNFPA State of world population 2000: Lives together, worlds apart, men and women in time of change. http:// www.unfpa.org/ swp/ 2000/ english/ ch01.html (accessed 6 J une 2007).

Vetten, L., \& Bhana, K. (2001). Violence, vengeance and gender: A preliminary investigation into the links between HIV/AIDS and violence against women in South Africa. J ohannesburg, South Africa: Centre for the Study of Violence and Reconciliation. West, C., \& Zimmerman, D. H. (1987). Doing gender. Gender and Society, 1, 125- 51.

Wood, K., Maforah, F., \&J ewkes, R. (1998). 'He forced me to love him': Putting violence on adolescent sexual health agendas. Social Science \& Medicine, 47(2), 233- 242.

\section{https://repository.uwc.ac.za/}

